Original Article

\title{
Episode of Hepatitis C viral infection in the people of Swat, Pakistan
}

\author{
Episódio de infecção viral por Hepatite C no povo de Swat, Paquistão
}

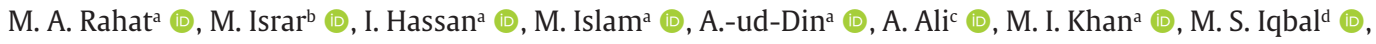

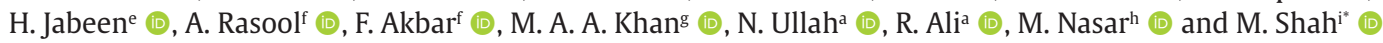 \\ aDepartment of Genetics, Hazara University, Mansehra, Pakistan \\ ${ }^{b}$ Department of Forensic Sciences, University of Swat, Swat, Pakistan \\ cDepartment of Biochemistry, Saidu Medical College, Saidu Sharif Swat, Pakistan \\ ${ }^{\mathrm{d} D e p a r t m e n t}$ of Botany, University of Gujrat, Gujrat, Pakistan \\ eDepartment of Microbiology, Women University Mardan, Pakistan \\ ${ }_{\mathrm{f}}$ Centre for Biotechnology \& Microbiology, University of Swat, Swat-19201, Pakistan \\ gCentre for Biotechnology \& Microbiology, University of Peshawar, Pakistan \\ hDepartment of Biosciences, COMSAT University Islamabad, Pakistan \\ ${ }^{i}$ Center for Animal Sciences \& Fisheries, University of Swat, Swat, Pakistan
}

\begin{abstract}
Infectious agents cause serious diseases in humans worldwide and are responsible for the high rate of morbidity and mortality. The prevalence and epidemiology of infectious disease (HCV) in the hospital visited patients referred by the physicians through the initial findings and their associated risk factors were studied in Swat. The data of 174 infected patients were collected during the period of 2015 to 2017 from two clinical laboratories of Tehsil Matta Swat. Inform consent form was taken before blood collection. After taking informed consent blood samples were collected and ICT test was performed and then ICT positive cases were conform through PCR. A total of 174 ICT positive samples [106 male and 68 females] were included in this study. Age was considered from 10 to 72 years. Of the 174 ICT strip positive, 99 [63 males, 36 females] were confirmed through PCR. The prevalence rate was recorded 56.89\%. I.V/I.M injection was recorded in $100 \%$ of the individuals. Visits to the barber shop was reported in (58\%) of the individuals, married individuals were (81.0), surgical operation was reported in (44.8\%), sharing toothbrush was observed in (29.9\%), piercing was reported in (39.7\%), family history was reported in $(26.4 \%)$, dental treatment was observed in (21.8\%), jaundice were (13.2\%) and tattooing was (1.7\%). Blood transfusion, surgical operations, Jaundice, family history and dental treatment were found significant risk factors for acquiring HCV infection. It was concluded that proper implementation of precautionary measures should be needed to control the spread of HCV in far near future.
\end{abstract}

Keywords: viral hepatitis C, Anti HCV Antibodies, risk factors, disease frequency, swat.

\section{RESUMO}

Agentes infecciosos causam doenças graves em humanos em todo o mundo, e são responsáveis pelo alto índice de morbimortalidade. A prevalência e a epidemiologia das doenças infecciosas no hospital que atendeu pacientes encaminhados pelos médicos por meio dos achados iniciais e seus fatores de risco associados foram estudadas em Peshawar. Os dados de 174 pacientes infectados foram coletados durante o período de 2015 a 2017 oriundos de dois laboratórios clínicos de Tehsil Matta Swat. O formulário de consentimento informado foi obtido antes da coleta de sangue. Após a obtenção do consentimento informado, foram coletadas amostras de sangue e foi realizado o teste ICT e, em seguida, os casos ICT positivos foram confirmados por PCR. Um total de 174 amostras ICT positivas [106 homens e 68 mulheres] foi incluído neste estudo. A idade considerada foi de 10 a 72 anos. Das 174 tiras de ICT positivas, 99 casos [63 homens, 36 mulheres] foram confirmados por PCR. A taxa de prevalência foi de 56,89\%. A injeção IV / IM foi registrada em 100\% dos indivíduos. A visita à barbearia foi relatada em (58\%) dos indivíduos, os números de casados foram (81,0\%), e a operação cirúrgica foi relatada em (44,8\%), o compartilhamento de escova de dente foi observado em (29,9\%), o piercing foi relatado em (39,7\%), antecedentes familiares foram relatados em (26,4\%), tratamento odontológico em (21,8\%), icterícia (13,2\%) e tatuagem em (1,7\%). Transfusão de sangue, operações cirúrgicas, icterícia, histórico familiar e tratamento odontológico foram fatores de risco significativos para adquirir infecção por Vírus da Hepatite C (VHC). Concluiu-se que a implementação adequada de medidas de precaução deve ser necessária para controlar a propagação do VHC em um futuro próximo.

Palavras-chave: hepatite C viral, anticorpos anti-VHC, fatores de risco, frequência da doença, swat.

*e-mail: muzafar@uswat.edu.pk

Received: September 07, 2020 - Accepted: December 09, 2020 


\section{Introduction}

Disease with hepatitis C virus (HCV) is a noteworthy worldwide wellbeing concern. It is expected that about 170 million individuals are contaminated with HCV around the world; this ailment is turned out to be a heightening financial, social and wellbeing trouble (Lavanchy, 2011). The weight of this sickness in a significant number of the developed and developing nations is consistently on the ascent (Hajarizadeh et al., 2013). Even though pervasiveness of HCV infection appears to have declined in the previous two decades in the vast majority of the developed nations of the world like, USA, Europe (Western and Northern), Australia and Japan (Razali et al., 2007). The occurrence of HCV differs by area. HCV occurrence less than $2 \%$ was noted in areas as America, Europe (Western) and Australia, while zones with the most astounding HCV infection are Africa and the Mediterranean (eastern) (Lavanchy, 2011). Hepatitis C Virus belongs to the family Flaviviridae with an around $9.6 \mathrm{~kb}$, single-stranded RNA genome. Due to the poor constancy of HCV RNA dependent NS5B protein, the virus displays an abnormal state of arrangement heterogeneity (Moradpour et al., 2007). Considering grouping homology six noteworthy HCV genotypes (Duberg et al., 2008) and various distinctive subtypes e.g. $1 \mathrm{~b}, 3 \mathrm{a}$ and so forth, have so far been recognized (WHO, 2003). Hepatitis C is the main source of end stage liver disease, including HCC (Hepatocellular carcinoma) and requirement for liver transplantation; recurrence of these was anticipated to build up 2-3 folds by 2030 (Dufour, 2004). Increased hazard of injection practices is the main source of HCV disease among drug abusers. There were almost 13.2 million drug abusers around the world (Aceijas et al., 2004) and half of them appear to have been infected with HCV (Aceijas and Rhodes, 2007).

$\mathrm{HCV}$ is commonly spread in Pakistan and its load is predicted to extend in upcoming decades due to extensive use of insecure medical practices. The occurrence of Hepatitis C virus infection in Pakistan had been evaluated on past and about 86 such studies are reported in the literature. Therefore, an improved efficient study was required to integrate the new information. A precise audit of information performed between 2010 and 2015 demonstrated that HCV sero-prevalence amongst the common adult Pakistani populace was $6.8 \%$, while recent data on HCV established was around $6.0 \%$ of the population. In most surveys, it was indicated that HCV infection was high in rural and peri urban areas (up to 25\%) (Umer and Iqbal, 2016). In Pakistan, there are different risk factors as compared to rest of the globe. $\mathrm{HCV}$ infection transmission is usually related to infected blood (blood products), drug addicts (intravenous), and needle pricking mostly accidentally or perinatal. Vertical and sexual routes are also reported as less frequent causes of HVC transmission (Dufour, 2004). Current research was aimed to identify different hazard factors among patients with HCV infection by analyzing their impact in our local community setup.

\section{Materials and Methods}

\subsection{Data collection}

Prevalence and clinical epidemiology of infectious agents related data were collected from hospitalized infected patients referred by the physicians through the initial findings, who have been visited to either of the two main clinical laboratories, Ahmad diagnostic center and Eilahi clinical laboratory opposite THQ hospital Mirkhel medical plaza Matta swat. The data were collected with the proper approval of the authorities from infected patients in the period of 2015 to 2017. The data of 174 infected patients were traced and recorded. The data according to the prevalence and epidemiology related information was recorded. Finally, calculate the infectious agents/ diseases frequency and percentage.

\subsection{Sample screening}

Individual's ages from 10 to 72 years was considered in the present study. $5 \mathrm{ml}$ blood was collected with the help of sterile syringe. The isolated samples were transferred to the laboratory and processed to collect the serum and further to screen out the hepatitis $C$ virus by screening kits (ICT: ACON, ACON Laboratories Inc., San Diego, CA 92121, USA) (Kalim et al., 2017; Rahat et al., 2018).

\subsection{PCR confirmation}

Total viral RNA was extracted using TRIzol reagent kit (Invitrogen Inc.) following the manufacturer's protocol. cDNA was obtained by reverse polymerases (MMLVMoloney Murine Leukemia Virus) and the final product was used for PCR amplification. Two round PCR and two sets of primer (Table 1). Infection of HCV was detected on $1 \%$ agarose gel and the band were observed an under UV light (Figure 1).

\subsection{Statistical Analysis}

Statistical analysis was done using SPSSv23 (IBM SPSS Statistics Inc) to find out the percentage, frequency and correlation among the hepatitis $\mathrm{C}$ with rick factor.

\section{Result}

\subsection{Prevalence of $\mathrm{HCV}$}

Males were (60.91\%) and females were (39.1\%) in the study population. ICT result shows $100 \%$ individuals are positive, but after by PCR conformation the result shows (59.43\%) males and (52.94\%) females were infected with HCV. Overall prevalence was recorded $56.89 \%$ (Table 2).

\subsection{Age wise prevalence of $\mathrm{HCV}$}

10-72 year of individuals were considered and further divided into 6 age groups. A maximum number of the affected was in the age group of $41-50$ consisted (28.16\%) individuals followed by 31 to 41 age group, $25.28 \%$, 51-60 (16.66\%), 21 to 30 (14.94\%), 61 and above (6.89\%) and 10 to $20(4.59 \%$ ) (Table 3$)$. 
Table 1. First \& Second round primer used in the study.

\begin{tabular}{ccc}
\hline Round & Primer & Forward/ Reverse \\
\hline First Round & CCCTGTGNNNNNCTGTCTTCACGC & Forward direction \\
& ACTCGCAAGCNNNNNAGGCAGTAC & Reverse direction \\
\multirow{2}{*}{ Second Round } & GAAAGCGTNNNNNTGGCG & Forward direction \\
& CACAAGGNNNNNCGACC & Reverse direction \\
\hline
\end{tabular}

Table 2. Hepatitis positive patient among total screened samples.

\begin{tabular}{ccccccc}
\hline Gender & Frequency & \% of population & ICT + samples & \% of ICT & PCR + samples & PCR \% \\
\hline Male & 106 & 60.91 & 106 & 60.91 & 63 & 63.63 \\
Female & 68 & 39.1 & 68 & 68 & 36 & 36.36 \\
Total & 174 & 100.0 & 174 & 174 & 99 & 100 \\
\hline
\end{tabular}

Table 3. Age wise prevalence of HCV.

\begin{tabular}{cccccccc}
\hline Gender & $\mathbf{1 0 - 2 0}$ & $\mathbf{2 1 - 3 0}$ & $\mathbf{3 1 - 4 0}$ & $\mathbf{4 1 - 5 0}$ & $\mathbf{5 1 - 6 0}$ & $\mathbf{6 1 - a b o v e}$ & Total \\
\hline Male & 5 & 19 & 28 & 23 & 19 & 12 & 106 \\
Female & 3 & 7 & 16 & 26 & 10 & 6 & 68 \\
Percentage & 4.59 & 14.94 & 25.28 & 28.16 & 16.66 & 10.34 & 100 \\
Total & 8 & 26 & 44 & 49 & 29 & 18 & 174 \\
\hline
\end{tabular}

Table 4. Statistics of HCV risk factors and co-morbidities. $\mathrm{n}=174$.

\begin{tabular}{|c|c|c|c|c|c|c|}
\hline \multirow{2}{*}{$\begin{array}{l}\text { Selected } \\
\text { Perimeter of } \\
\text { the study }\end{array}$} & \multicolumn{2}{|c|}{$\begin{array}{c}\text { Number of male \& Female in the } \\
\text { study population }\end{array}$} & \multicolumn{2}{|c|}{$\begin{array}{l}\text { Percentage of Male \& Female in } \\
\text { the study }\end{array}$} & \multirow{2}{*}{$\begin{array}{c}\text { Total } \\
\text { individual }\end{array}$} & \multirow{2}{*}{$\begin{array}{c}\text { Total } \\
\text { Percentage }\end{array}$} \\
\hline & Male & Female & Male & Female & & \\
\hline Married & 78 & 63 & 55.31 & 44.68 & 141 & 81.0 \\
\hline Family history & 27 & 19 & 58.69 & 41.30 & 46 & 26.4 \\
\hline $\begin{array}{l}\text { Visited to } \\
\text { barbershop }\end{array}$ & 101 & 1 & 99.1 & 0.98 & 102 & 58.6 \\
\hline $\begin{array}{l}\text { Sharing tooth } \\
\text { brush }\end{array}$ & 28 & 24 & 53.84 & 46.15 & 52 & 29.9 \\
\hline Tattooing & 3 & 0 & 100 & 0 & 3 & 1.7 \\
\hline I.V/I.M Inj & 106 & 68 & 60.91 & 39.08 & 174 & 100.0 \\
\hline $\begin{array}{l}\text { Blood } \\
\text { transfusion }\end{array}$ & 28 & 12 & 70 & 30 & 40 & 23.0 \\
\hline $\begin{array}{l}\text { Dental } \\
\text { Treatment }\end{array}$ & 20 & 18 & 52.63 & 47.36 & 38 & 21.8 \\
\hline Jaundice & 12 & 11 & 52.17 & 47.82 & 23 & 13.2 \\
\hline Piercing & 2 & 67 & 2.89 & 97.10 & 69 & 39.7 \\
\hline $\begin{array}{c}\text { Surgical } \\
\text { operation }\end{array}$ & 41 & 37 & 52.56 & 47.43 & 78 & 44.8 \\
\hline
\end{tabular}

\subsection{Demographic Variables}

In the current study (81.0\%) individuals were married. HCV positive family history was founded in (26.4\%) followed by individual who visited to the barber shop were (58.6\%), those who sharing tooth brush (29.9\%), tattooing (1.7\%), and I.V/I.M injection was (100\%), Blood transfusion was recorded in (23.0\%), dental treatment in (21.8\%), jaundice in (13.2\%), piercing (39.7\%) and surgical operation were reported in (44.8\%) (Table 4$)$.

3.4. Correlation between different risk factors in subjects with HCV

The typical thing in our research was that in the majority of patients there was more than one risk factor. Tattoo 


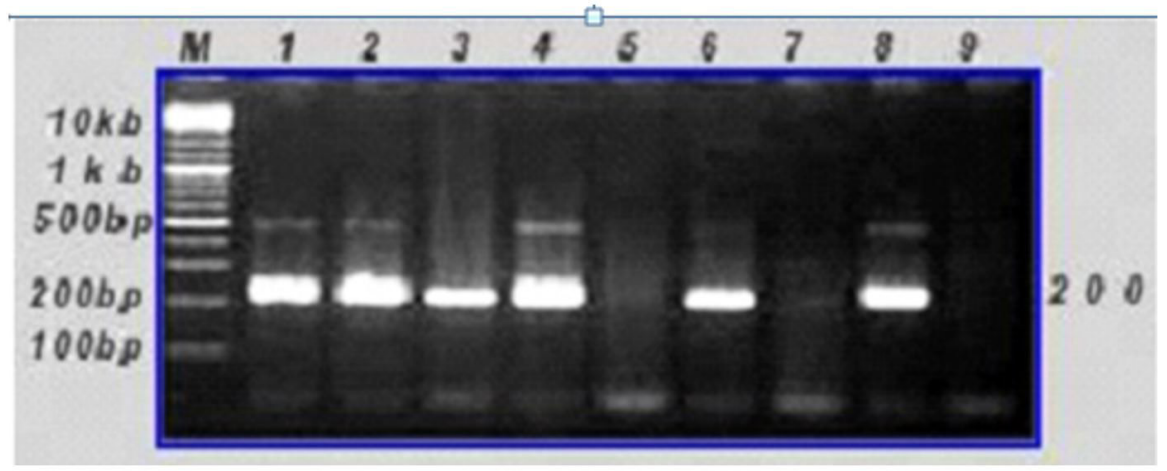

Figure 1. Gel photograph of PCR product. 1\% agarose gel was used. Line 1 indicate 100bp ladder. Lane 5, 7 negative results while the remaining lanes indicate a positive result.

marks were less common in our locality, surgical and dental procedures, Jaundice, family history were a special matter of concern to control. Pearson Correlation Sig. (2-tailed) of HCV was related to various risk factors which were statistically at significant levels. The correlations of various risk factors were shown in (Table 5).

\section{Discussion}

Infections caused by the pathogenic agents cause serious diseases in humans and are responsible for the higher rate of morbidity/mortality in human population worldwide. In the present study it is reported that $56.89 \%$ of individuals are reported positive for $\mathrm{HCV}$ infection. But previous studies show different results (Kalim et al., 2017) conducted a study on orphan individuals and reported $34.85 \%$ another study by (Ahmad et al., 2009) reported $13.8 \%$. It the present study, none of the co- infection were reported both of hepatitis B and C virus. But previous studies show different results to our study (Baig et al., 2009) reported a higher frequency of co- infection working on cirrhosis patients in Pakistan. Sarwar and co-workers from different area of Abbottabad region reported $40 \%$ of co-infection in the study population (Sarwar et al., 2008). Higher Prevanlce in our study may be due to the infected individuals who visited to doctor clinic. But previous data show general population. In the present study, we also found that the prevalence of HCV is male individuals more compared to female individuals. A similar study was reported by (Muhammad and Jan, 2005).

In the current study higher prevalence rate was found in the age group of 41-50. Similar report to our study shown by (Al-Hegami et al., 2015 Almezgagi et al., 2020). But the study of (Baghza, 2014) observed the high prevalence of HCV infection was (13\%) among the age group more than 65 years.

In the present study (39.7\%) subjects with a history of needle pricking by non-medical and medical professionals, accidentally or nose and ear piercing. Needle pricking ratio was very high in local setup. Previous studies conducted in Iran analyzed strong association of HCV seropositive with injections, tattooing, sharing equipment and history of imprison (Mir-Nasseri et al., 2011; Nokhodian et al., 2012; Sharhani et al., 2017). Previous studies on needle pricking, recapping needle pricking syringes were responsible for 2 to $10 \%$ transmission of hepatitis $C$ in health care worker (Hamid et al., 1999; Mujeeb et al., 1998; Aziz et al., 2002) another study in Mirpur Khas, Hyderabad and Sukkur the incident of hepatitis $\mathrm{C}$ virus among the population sharing reused of injection equipment were reported $68 \%, 8.5 \%$ and 33.6\% respectively (Altaf et al., 2009; Janjua et al., 2005). Incidence of hepatitis $C$ virus in drug abusers was not reported in our study as no one was positive for $\mathrm{HCV}$, but a previous study showed the incidence was $17.7 \%$ to $57 \%$ (Kuo et al., 2006; Achakzai et al., 2007; Platt et al., 2009).

In the current study (23\%) subject was identified that had a history of blood transfusion. Compared to previous studies, its show different results, $48.67 \% \pm 1.75 \%$ hepatitis $\mathrm{C}$ were reported in blood disorders, population (Hussain et al., 2008). A similar study was conducted by Luby et al. (2000) reported that $25 \%$ of blood blanks do not follow WHO recommended criteria during blood collection, but only $23 \%$ fulfill the recommend criteria. About $66 \%$ of the Pakistani population belongs to the rural community where blood transfusion facilities are insufficient. At the Pakistan round about 1.2 - 1.5 million transfusions are given each year as reported by W.H.O (Asif et al., 2004). Professional donors should be discouraged to promote the hazard-free blood supply (Luby et al., 2000).

In the current study (58.6\%) male and female subjects had a history of barber history. Barbers in Pakistan and other developing nations usually do not have knowledge of health-related infections which they spread through reuse of unsterilized razors and scissors (Khaliq and Smego, 2008). Approximately $13 \%$ of barbers were aware that hepatitis could be transmitted by contaminated razors/scissors, etc. (Janjua and Nizamy, 2004). Studies show that most of the barbers are performing shavings in contaminated conditions and do not know about HCV infection (Wazir et al., 2008). Viral hepatitis $C$ was present in $70.0 \%$ of facial and $48.0 \%$ of axillary shavings by barbers (Bari et al., 2001).

Major and minor surgical procedures were also analyzed in the current study. History of surgery subjects (44.8\%), dental treatment were reported in $21.8 \%$.

The prevalence of hepatitis c was significantly higher among patients with a history of blood transfusion. A. significant relationship was found between the hepatitis 
至莺| 焉

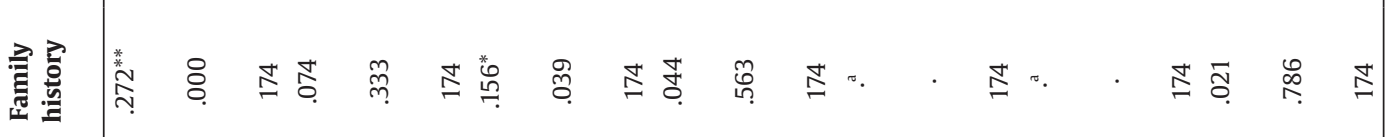

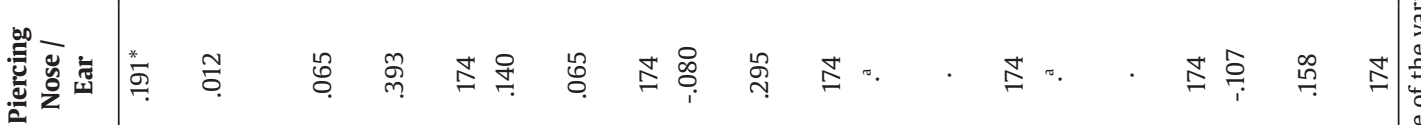

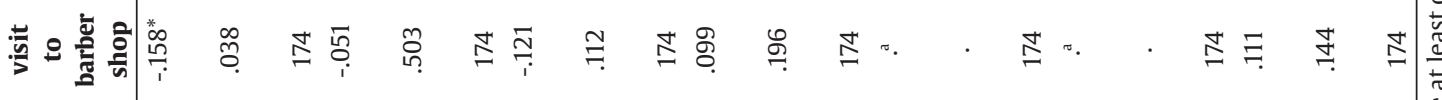

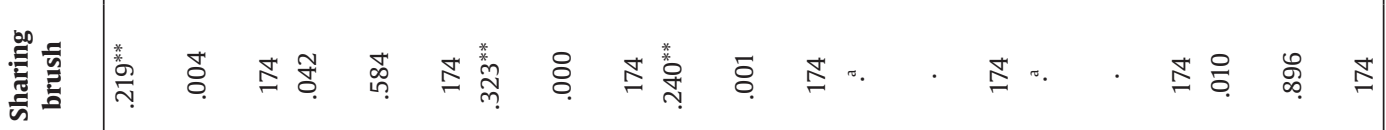

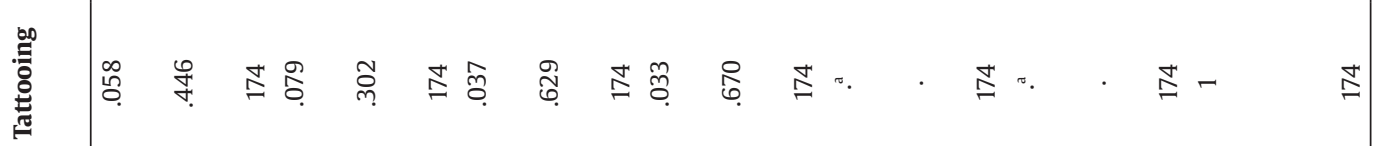

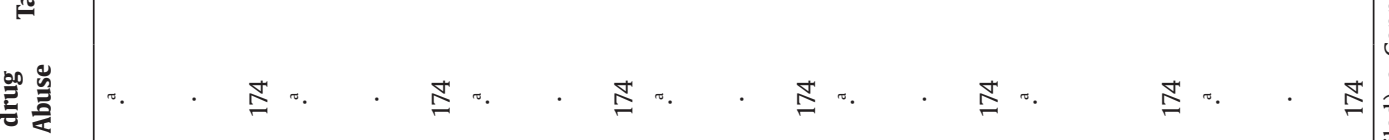

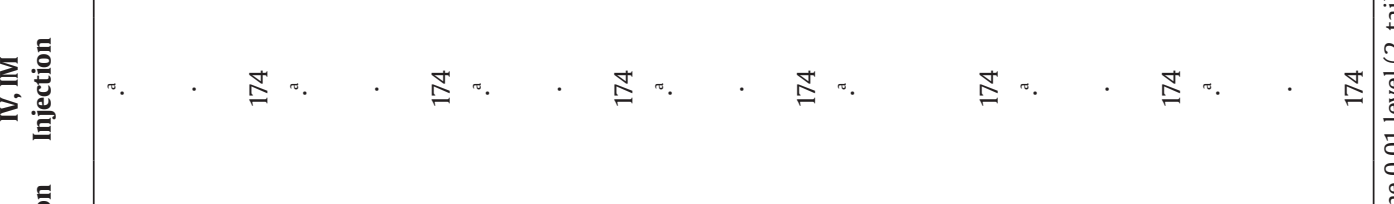
đํ.

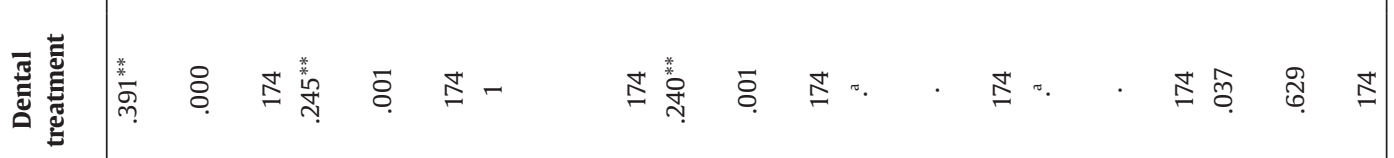
疍

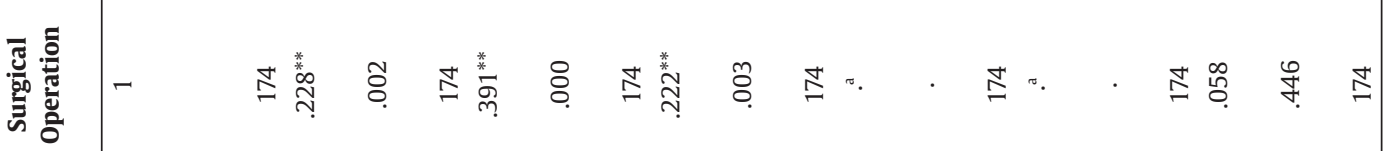

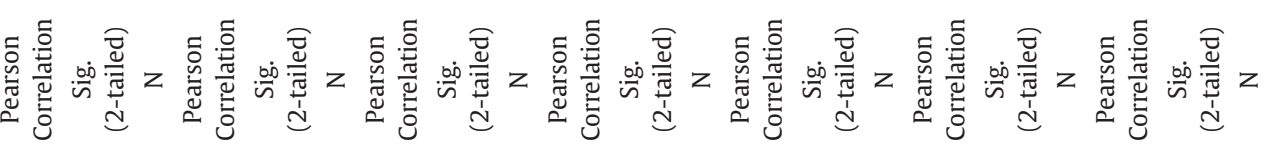

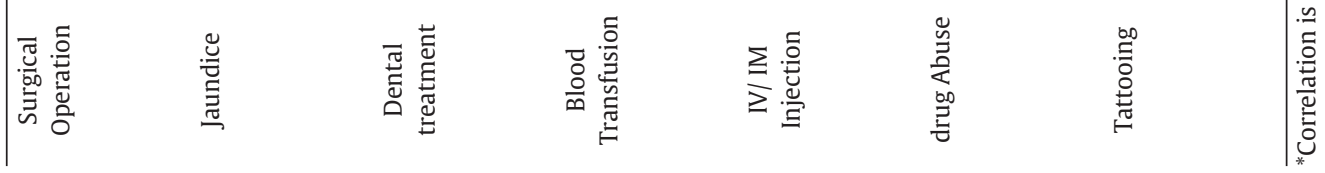




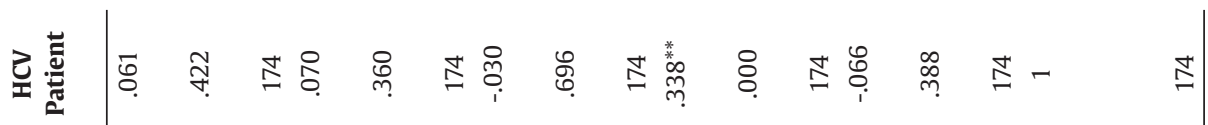

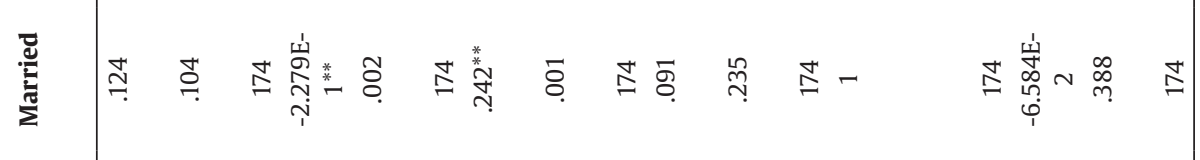

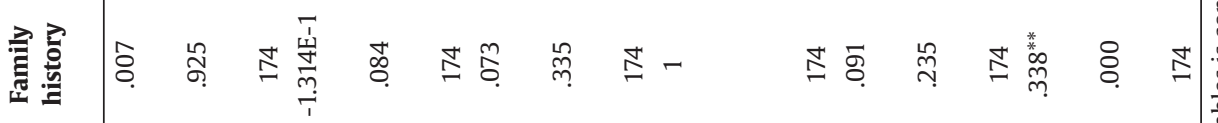

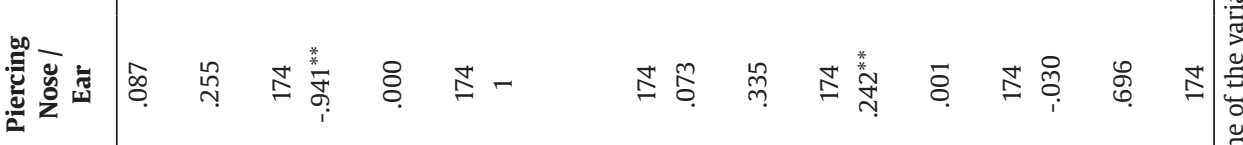

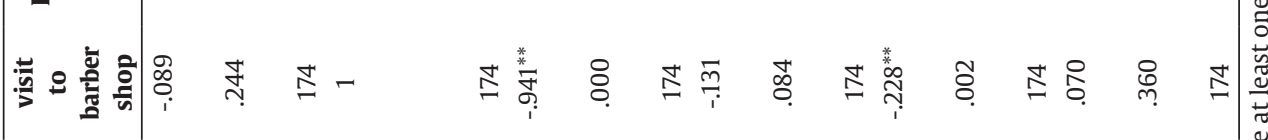

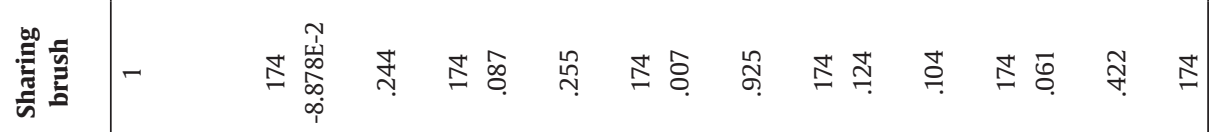
高

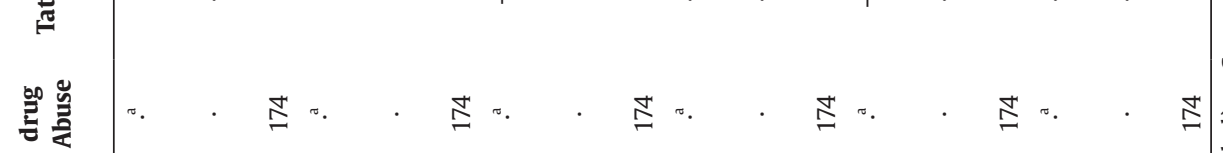

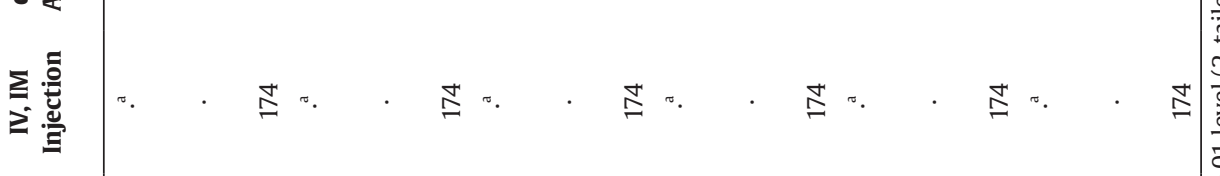

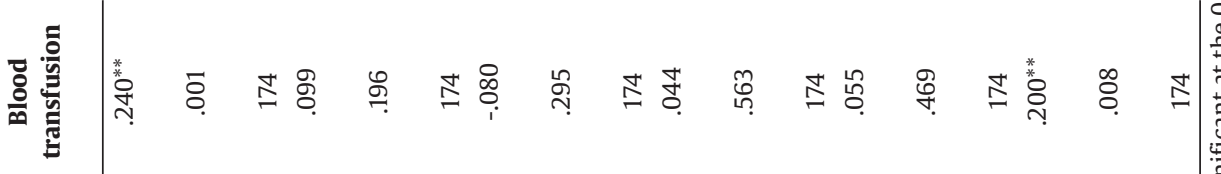
焉焉

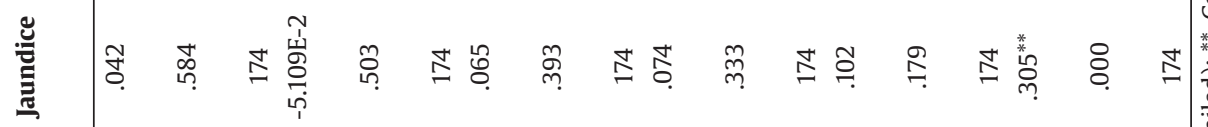

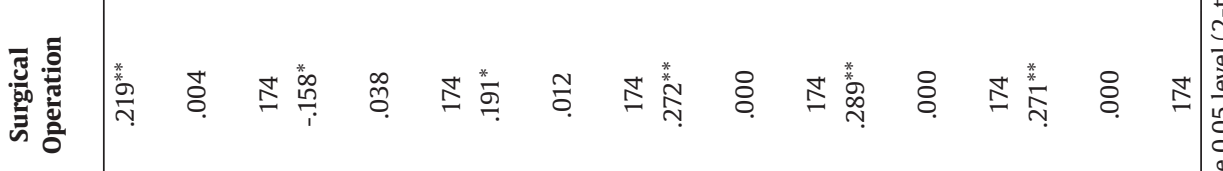

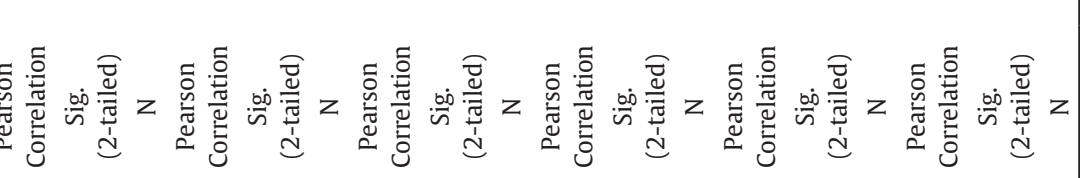

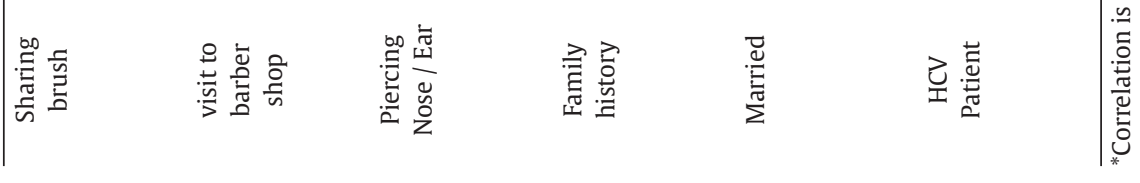


c virus with blood transfusion, surgical procedures, dentist visit, family history and jaundice.

\section{Conclusion}

In the present study it is concluded the Needle pricking, Jaundice, family history, blood products and dental procedures are common risk factors in our research.

\section{Recommendations}

It is recommended that there should be a national screening plan for hepatitis $C$. All subjects who are at risk must be investigated earlier. Screening program at national level should be started in early childhood. Early diagnosis and immediate treatment at standard levels (recommended by WHO/FDA and other international agencies) should be applied in large scale. Medical, surgical and dental instruments should be checked at international standards to avoid contamination. Health education may play vital role in the control of different preventable risk factors.

\section{References}

ACEIJAS, C. and RHODES, T., 2007. Global estimates of prevalence of HCV infection among injecting drug users. The International Journal on Drug Policy, vol. 18, no. 5, pp. 352-358. http://dx.doi. org/10.1016/j.drugpo.2007.04.004. PMid:17854722.

ACEIJAS, C., STIMSON, G.V., HICKMAN, M. and RHODES, T., 2004. Global overview of injecting drug use and HIV infection among injecting drug users. AIDS, vol. 18, no. 17, pp. 22952303. http://dx.doi.org/10.1097/00002030-200411190-00010. PMid:15577542.

ACHAKZAI, M., KASSI, M. and KASI, P.M., 2007. Seroprevalences and co-infections of HIV, hepatitis C virus and hepatitis B virus in injecting drug users in Quetta, Pakistan. Tropical Doctor, vol. 37, no. 1, pp. 43-45. http://dx.doi.org/10.1258/004947507779951989. PMid:17326891.

AHMAD, A., AHMAD, B., ALI, A. and AHMAD, Y., 2009. Seroprevalence of HBsAg and anti-HCV in general healthy population of Swat district with frequency of different HCV Genotypes. Pakistan Journal of Medical Sciences, vol. 25, no. 5, pp. 744-748.

AL-HEGAMI, M., AL-MAMARI, A., S. AL-KADASSE, A., AL-GASHA'A, F.A.S., AL-HAG, S. and AL-HEGAMI, A.A.S., 2015. Prevalence and risk factors of hepatitis $B$ and hepatitis $C$ virus infections among patients with chronic renal failure in Zabeed city, Yemen Republic. Open Journal of Medical Microbiology, vol. 5, pp. 136142. http://dx.doi.org/10.4236/ojmm.2015.53017.

ALMEZGAGI, M.M., EDREES, W.H., AL-SHEHARI, W.A., AL-MOYED, K., AL-KHWLANY, R.S. and ABBAS, A.B. 2020. Prevalence of Hepatitis B Virus and Hepatitis C Virus and Associated Risk Factors among Hemodialysis Patients in Ibb City-Yemen. PSM Microbiol, vol. 5, no. 2, pp. 32-40.

ALTAF, A., SALEEM, N., ABBAS, S. and MUZAFFAR, R., 2009. High prevalence of HIV infection among injection drug users (IDUs) in Hyderabad and Sukkur, Pakistan. The Journal of the Pakistan Medical Association, vol. 59, no. 3, pp. 136-140. PMid:19288936.

ASIF, N., KHOKHAR, N. and ILAHI, F., 2004. Sero-prevalence of HBV, $\mathrm{HCV}$, and HIV infection among voluntary non remunerated \& replacement donors in Northern Pakistan. Pakistan Journal of Medical Sciences, vol. 20, no. 1, pp. 24-28.

AZIZ, S., MEMON, A., TILY, H.I., RASHEED, K., JEHANGIR, K. and QURAISHY, M.S., 2002. Prevalence of HIV, hepatitis B and C amongst health workers of Civil Hospital Karachi. The Journal of the Pakistan Medical Association, vol. 52, no. 3, pp. 92-94. PMid: 12071075.

BAGHZA, M.N., 2014. The prevalence of hepatitis C virus among hemodialysis patients in yemen. Journal of Purity, Utility Reaction and Environment, vol. 3, no. 4, pp. 221-225.

BAIG, S., SIDDIQUI, A.A., AHMED, W.U., QURESHI, H. and ARIF, A., 2009. Frequency of hepatitis $C$ and $D$ super infection in patients with hepatitis B related complex liver disorders. Journal of the College of Physicians and Surgeons - Pakistan, vol. 19, no. 11, pp. 699-703. PMid:19889265.

BARI, A., AKHTAR, S., RAHBAR, M.H. and LUBY, S.P., 2001. Risk factors for hepatitis $C$ virus infection in male adults in RawalpindiIslamabad, Pakistan. Tropical Medicine E' International Health, vol. 6, no. 9, pp. 732-738. http://dx.doi.org/10.1046/j.13653156.2001.00779.x. PMid:11555441.

DUBERG, A., JANZON, R., BÄCK, E., EKDAHL, K. and BLAXHULT, A., 2008. The epidemiology of hepatitis $C$ virus infection in Sweden. Eurosurveillance, vol. 13, no. 21, pp. 18882. http:// dx.doi.org/10.2807/ese.13.21.18882-en. PMid:18761966.

DUFOUR, D.R., 2004. Lot-to-lot variation in anti-hepatitis C signal-tocutoff ratio. Clinical Chemistry, vol.50, no. 5, pp. 958-960. http:// dx.doi.org/10.1373/clinchem.2003.031039. PMid:15105361.

HAJARIZADEH, B., GREBELY, J. and DORE, G.J., 2013. Epidemiology and natural history of HCV infection. Nature Reviews. Gastroenterology \& Hepatology, vol. 10, no. 9, pp. 553-562. http://dx.doi.org/10.1038/nrgastro.2013.107. PMid:23817321.

HAMID, S.S., FAROOQUI, B., RIZVI, Q., SULTANA, T. and SIDDIQUI, A.A., 1999. Risk of transmission and features of hepatitis $C$ after needlestick injuries. Infection Control and Hospital Epidemiology, vol. 20, no. 1, pp. 63-64. http://dx.doi.org/10.1086/501547. PMid:9927271.

HUSSAIN, H., IQBAL, R., KHAN, M.H., IFTIKHAR, B., AZIZ, S., BURKI, F.K., HASSAN, M., NISAR, Y.B. and KRISHAN, J., 2008. Prevalence of hepatitis $C$ in beta thalassaemia major. Gomal Journal of Medical Sciences, vol. 6, no. 2, pp. 87-90.

JANJUA, N.Z. and NIZAMY, M.A.M., 2004. Knowledge and practices of barbers about hepatitis $B$ and $C$ transmission in Rawalpindi and Islamabad. The Journal of the Pakistan Medical Association, vol. 54, no. 3, pp. 116-119. PMid:15129868.

JANJUA, N.Z., AKHTAR, S. and HUTIN, Y.J., 2005. Injection use in two districts of pakistan: implications for disease prevention. International Journal of Health Care Quality Assurance, vol. 17, no. 5, pp. 401-408. http://dx.doi.org/10.1093/intqhc/mzi048. PMid:15883127.

KALIM, M., AHMAD, H., RAUF, A., NADEEM, S., RAHAT, M.A. and SHAFIQ D., 2017. Incidence of HBV and HCV in Young Orphan Students of Swat. PSM Biological Research, vol. 2, no. 3, pp. 128-132.

KHALIQ, A.A. and SMEGO, R.A., 2008. Barber shaving and bloodborne disease transmission in developing countries. South African Medical Journal, vol. 95, no. 2, pp. 94-96. PMid:15751200.

KUO, I., GALAI, N., THOMAS, D.L., ZAFAR, T., AHMED, M.A. and STRATHDEE, S.A., 2006. High HCV seroprevalence and HIV drug use risk behaviors among injection drug users in Pakistan. Harm Reduction Journal, vol. 3, no. 1, pp. 26. http://dx.doi. org/10.1186/1477-7517-3-26. PMid:16914042.

LAVANCHY, D., 2011. Evolving epidemiology of hepatitis C virus. Clinical Microbiology and Infection, vol. 17, no. 2, pp. 107- 
115. http://dx.doi.org/10.1111/j.1469-0691.2010.03432.x. PMid:21091831.

LUBY, S., KHANANI, R., ZIA, M., VELLANI, Z., ALI, M., QURESHI, A.H., KHAN, A.J., MUJEEB, S.A., SHAH, S.A. and FISHER-HOCH, S., 2000. Evaluation of blood bank practices in Karachi, Pakistan, and the government's response. Health Policy and Planning, vol. 15, no. 2, pp. 217-222. http://dx.doi.org/10.1093/heapol/15.2.217. PMid:10837045.

MIR-NASSERI, M.M., MOHAMMADKHANI, A., TAVAKKOLI, H., ANSARI, E. and POUSTCHI, H., 2011. Incarceration is a major risk factor for blood-borne infection among intravenous drug users: incarceration and blood borne infection among intravenous drug users. Hepatitis Monthly, vol. 11, no. 1, pp. 19-22. PMid:22087111.

MORADPOUR, D., PENIN, F. and RICE, C.M., 2007. Replication of hepatitis C virus. Nature Reviews. Microbiology, vol. 5, no. 6, pp. 453-463. http://dx.doi.org/10.1038/nrmicro1645. PMid:17487147.

MUHAMMAD, N. and JAN, M.A., 2005. Frequency of hepatitis "C" in Buner, NWFP. Journal of the College of Physicians and Surgeons-Pakistan, vol. 15, no. 1, pp. 11-14. PMid:15670516.

MUJEEB, S.A., KHATRI, Y. and KHANANI, R., 1998. Frequency of parenteral exposure and seroprevalence of $\mathrm{HBV}, \mathrm{HCV}$, and HIV among operation room personnel. The Journal of Hospital Infection, vol. 38, no. 2, pp. 133-137. http://dx.doi.org/10.1016/ S0195-6701(98)90066-4. PMid:9522291.

NOKHODIAN, Z., MESHKATI, M., ADIBI, P., ATAEI, B., KASSAIAN, N., YARAN, M., SHOAEI, P. and HASSANNEJAD, R., 2012. Hepatitis $C$ among intravenous drug users in Isfahan, Iran: a study of seroprevalence and risk factors. International Journal of Preventive Medicine, vol. 3, no. 1, suppl. 1, pp. 131. PMid:22826755.

PLATT, L., VICKERMAN, P., COLLUMBIEN, M., HASAN, S., LALJI, N., MAYHEW, S., MUZAFFAR, R., ANDREASEN, A. and HAWKES, S., 2009. Prevalence of HIV, HCV and sexually transmitted infections among injecting drug users in Rawalpindi and Abbottabad, Pakistan: evidence for an emerging injection- related HIV epidemic. Journal of Sexually Transmitted Diseases, vol. 85, no. 2, suppl. 2, pp. ii17-ii22. http://dx.doi.org/10.1136/ sti.2008.034090. PMid:19307346.

RAHAT, M.A., AHMED, H., KHAN, M. I., RAUF, A., ALI, A., KALIM, M. and KHAN, H., 2018. Incidence of Anti HbsAg and HCV in the Young Orphans of District Nowshera, Khyber Pakhtunkhwa, Pakistan. International Journal of Molecular Microbiology, vol. 1, no. 2, pp. 51-55.

RAZALI, K., THEIN, H.H., BELL, J., COOPER-STANBURY, M., DOLAN, K., DORE, G., GEORGE, J., KALDOR, J., KARVELAS, M., LI, J. and MAHER, L., 2007. Modelling the hepatitis C virus epidemic in Australia. Drug and alcohol dependence, vol .91, no. 2-3, pp. 228-235. https://doi.org/10.1016/j.drugalcdep.2007.05.026.

SARWAR, J., GUL, N., IDRIS, M., ANIS-UR-REHMAN., FARID, J. and ADEEL, M.Y., 2008. Seroprevalenceof hepatitis B and hepatitis $C$ in health care workers in Abbottabad. Journal of Ayub Medical College, Abbottabad, vol. 20, no. 3, pp. 27-29. PMid:19610509.

SHARHANI, A., MEHRABI, Y., NOROOZI, A., NASIRIAN, M., HIGGS, P., HAJEBI, A., HAMZEH, B., KHADEMI, N., NOROOZI, M., SHAKIBA, E. and ETEMAD, K., 2017. Hepatitis C VirusSeroprevalence and associated risk factors among male drug injectors in Kermanshah, Iran. Hepatitis Monthly, vol. 17, no. 10. http:// dx.doi.org/10.5812/hepatmon.58739.

UMER, M. and IQBAL, M., 2016. Hepatitis C virus prevalence and genotype distribution in Pakistan: comprehensive review of recent data. World Journal of Gastroenterology, vol. 22, no. 4, pp. 1684-1700. http://dx.doi.org/10.3748/wjg.v22.i4.1684. PMid:26819533.

WAZIR, M.S., MEHMOOD, S., AHMED, A. and JADOON, H.R. 2008. Awareness among barbers about health hazards associated with their profession. Journal of Ayub Medical College, vol. 20, no. 2, pp. 35-8.

WORLD HEALTH ORGANIZATION - WHO, 2003. Epidemic and Pandemic Alert and Response, Hepatitis C Virus. Genebra: World Health Organization. 